\title{
Microbial Processes in Ore-Bearing Laterite at the Tomtor Nb-REE Deposit: Evidence from Carbon Isotope Composition in Carbonates
}

\author{
V. Ponomarchuk ${ }^{(凶)}$, E. Lazareva, S. Zhmodik, N. Karmanov, \\ and A. Piryaev \\ Institute of Geology and Mineralogy SB RAS, Novosibirsk, Russia \\ ponomar@igm.nsc.ru
}

\begin{abstract}
The unique Nb-REE deposit is located within the Tomtor complex of ultramafic alkaline and carbonatite rocks in the northern Sakha Republic (Yakutia) (Kravchenko and Pokrovsky 1995; Dobretsov and Pokhilenko 2010; Lazareva et al. 2015). Ores reside in three layers (Severny, Yuzhny, and Buranny sites) which fill depressions in subsided profiles of weathered carbonatites. Judging by stable isotope analysis, carbonates from laterite weathering profiles at the Tomtor Nb-REE-deposit formed by different mechanisms, including microbially mediated organic-clastic sulfate reduction and anaerobic oxidation of methane.
\end{abstract}

Keywords: Tomtor $\cdot \mathrm{Nb}$-REE-deposit $\cdot$ Laterite $\cdot$ Carbonates $\cdot \mathrm{C}$-isotopes $\cdot$ Microbial $\cdot$ Methane

\section{Introduction}

Rare earth elements have been broadly used in advanced technologies. They often occur in carbonatite deposits among which laterite profiles of weathered carbonatites are most attractive commercial targets. A unique Nb-REE deposit is located within the Tomtor complex of ultramafic alkaline and carbonatite rocks in the northern Sakha Republic (Yakutia) (Kravchenko and Pokrovsky 1995; Dobretsov and Pokhilenko 2010; Lazareva et al. 2015). Ores reside in three layers (Severny, Yuzhny, and Buranny sites) which fill depressions in subsided profiles of weathered carbonatites. Lately, evidence has been obtained that localization of elements in ore-bearing beds may have biotic controls (Lazareva et al. 2015). The possible role of microorganisms in ore formation has not been discussed yet in the literature on laterite profiles from carbonatite deposits, including the giants of Mountain Weld (Australia) or Araxa and Catalão (Brazil). In this respect, the Tomtor deposit is remarkable by a contribution of biogenic and bacterial processes to its formation, besides magmatism and high-temperature hydrothermalism that are common to all carbonatite deposits. Biogenic agents are usually identified from the carbon isotope composition of rocks controlled by their interaction with fluids. The discussed stable isotope compositions of carbonates from ore-bearing laterites at the Tomtor deposit provide evidence of possible microbial mediation. 


\section{Methods and Approaches}

The stable isotope compositions were analyzed in three samples (TM-592, TM-590, and $\mathrm{BH} 101$ ) from laterite ore zones with $\sim 1 \%, 0.6 \%$, and $1.6 \%$ REE, respectively. Extraction of monofractions for analysis is difficult because the laterite samples are fine grained while the carbonates are zoned. The problem can be solved by using selective acid extraction based on progressively slower reactions of carbonates with $\mathrm{H}_{3} \mathrm{PO}_{4}$ in the stoichiometric series: calcite $\rightarrow$ dolomite $\rightarrow$ ankerite $\rightarrow$ siderite $\rightarrow$ rhodochrosite. According to experimental evidence (Al-Aasm et al. 1990), the reaction duration sufficient for $\delta^{13} \mathrm{C}$ determination is $1 \mathrm{~h}$ for calcite, $24 \mathrm{~h}$ for dolomite, and 5-7 days for siderite and rhodochrosite. The $\mathrm{C}$ and $\mathrm{O}$ isotope compositions of carbonates are determined by digestion in anhydrous $\mathrm{H}_{3} \mathrm{PO}_{4}$ followed by measurements on a FINNIGAN MAT-253 mass spectrometer with a GasBench II analyzer, in a stream of pure helium. The GasBench unit was also used for preconditioning of samples digested at $70{ }^{\circ} \mathrm{C}$. The results are quoted in (\%o) relative to the Vienna Peedee belemnite PDB standard for carbon and relative to SMOW for oxygen. The analytical errors were $\pm 0.1 \%$ o for carbon and $0.15 \%$ o for oxygen. The composition and morphology of minerals were studied at the Analytical Center of IGM (Novosibirsk) on a Tescan MIRA 3 LMU scanning electron microscope with Oxford Instruments Nanoanalysis Aztec Energy/INCA Energy 450+ XMax 80 and INCA Wave 500 analyzers, applicable to scan nanometer particles.

\section{Results and Discussion}

Sample TM-590 is composed mainly of goetite, siderite (with a Mn impurity), calcite, and rhodochrosite. Goethite occurs either as dripstone, with concentric zonation, or as pseudomorphs after a disappeared mineral. The carbonates exist as zoned anhedral grains, with calcite being the latest phase. Fine apatite crystals, pyroxene, monazite, pyrochlore, and sphalerite are present in lesser amounts. The rock-forming phases in TM-592 are goethite, siderite, and calcite and the accessories are apatite and monazite. Apatite occurs as fine prismatic euhedral grains in calcite. Sample BH 101 consists of finely intergrown Fe-chlorite (chamosite) and apatite. The apatite-chamosite aggregate encloses clearly seen large rhodochrosite grains with siderite in their core. The two phases have a distinct boundary but have inherited orientations of the crystallographic axes. The accessory phases are $\mathrm{TiO}_{2}$, submicrometer monazite platelets, sphalerite, and galena.

Synthesis of $\mathrm{C}$ and $\mathrm{O}$ isotope data from magmatic and postmagmatic (hydrothermal, metasomatic) carbonates in different carbonatite deposits world wide shows a large range of values from -10 to $+3 \%$ (PDB) for $\delta^{13} \mathrm{C}$ and from +6 to $+30 \%$ o (SMOW) for $\delta^{18} \mathrm{O}$ (Deines 1989).

The $\delta^{13} \mathrm{C}$ values obtained for the Tomtor samples (Table 1) are lower. The $\delta^{13} \mathrm{C}$ patterns in carbonates are controlled by the isotope composition of bicarbonate. Low $\delta^{13} \mathrm{C}$ in bicarbonate is due to oxidation of organic matter where $\delta^{13} \mathrm{C}$ can reach $-32 \%$ o (Oleary 1988). In the course of microbially mediated sulfate reduction of geopolymers and biopolymers in aerobic conditions, the $\delta^{13} \mathrm{C}$ values of bicarbonate that forms by 
reaction (1) and those of carbonate produced later by reaction (2) are inherited from the precursor component.

$$
\begin{gathered}
2 \mathrm{CH}_{2} \mathrm{O}+\mathrm{SO}_{4}^{2-} \rightarrow 2 \mathrm{HCO}^{3-}+\mathrm{H}_{2} \mathrm{~S} \\
2 \mathrm{HCO}^{3-}+\mathrm{Me}^{2+}=\mathrm{MeCO}_{3}+\mathrm{CO}_{2}+\mathrm{H}_{2} \mathrm{O}
\end{gathered}
$$

There are two facts that implicitly support the above considerations: laterite contains organic remnants (Lazareva et al. 2015) that are electron donors in reaction (1); the samples contain sulfides, including framboidal pyrite, which formed at the account of $\mathrm{H}_{2} \mathrm{~S}$ released in reaction (1). However, this model can account only for the isotope composition of the calcite component in TM-590, while other $\delta^{13} \mathrm{C}$ values $(-24.8 \%$ in TM-590) are below $-32 \%$, and may have formed with participation of methane. Biogenic methane has $-55 \%$ o to $-80 \%$ o $\delta^{13} \mathrm{C}$, and the $\delta^{13} \mathrm{C}$ values in bicarbonate resulting from microbially mediated methane oxidation (react/3) and in carbonate that formed later by reaction (2) will be low.

$$
\mathrm{CH}_{4}+\mathrm{SO}_{4}^{2-} \rightarrow \mathrm{HCO}^{3-}+\mathrm{HS}^{-}+\mathrm{H}_{2} \mathrm{O}
$$

Table 1. $\delta^{13} \mathrm{C}$ and $\delta^{18} \mathrm{O}(\%)$ in different fractions of carbonates

\begin{tabular}{l|l|l|l|l}
\hline \multicolumn{2}{l}{ Sample } & $1 \mathrm{~h}$ & $24 \mathrm{~h}$ & 7 days \\
\hline \multirow{2}{*}{ TM-590 } & $\delta^{13} \mathrm{C}$ & -29.6 & -39.2 & -24.8 \\
\cline { 2 - 5 } & $\delta^{18} \mathrm{O}$ & +12.0 & +16.1 & +14.6 \\
\hline \multirow{2}{*}{ TM-592 } & $\delta^{13} \mathrm{C}$ & -31.2 & -44.1 & -37.1 \\
\cline { 2 - 5 } & $\delta^{18} \mathrm{O}$ & +7.6 & +13.6 & +15.1 \\
\hline \multirow{2}{*}{ BH 101 } & $\delta^{13} \mathrm{C}$ & -59.0 & -54.6 & - \\
\cline { 2 - 5 } & $\delta^{18} \mathrm{O}$ & +9.4 & 10.5 & - \\
\hline
\end{tabular}

Note that a low value of $\delta^{13} \mathrm{C}$ was previously reported (Pokrovsky 1990; Kravchenko and Pokrovsky 1995) at the Tomtor deposit, but the mineralogical and geochemical characterization of the sample is not given.

\section{Conclusions}

The reported isotope data show that organic clastic sulfate reduction and anaerobic methane oxidation with participation of microbial communities were among key mechanisms responsible for the formation of carbonates in laterite profiles of the Tomtor Nb-REE deposit.

Acknowledgements. The study was supported by grant 18-17-00120 from the Russian Science Foundation. 


\section{References}

Al-Aasm IS, Taylor BE, South B (1990) Stable isotope analysis of multiple carbonate samples using selective acid extraction. Chem Geol Isot Geosci Sect 80(2):119-125

de Toledo MCM, de Oliveira SMB, Fontan F, Ferrari VC, de Parseval P (2004) Mineralogia, morfologia e cristaloquímica da monazita de Catalão I (GO, Brasil). Braz J Geol 34(1):135146

Deines P (1989) Stable isotope variations in carbonatites. In: Bell K (ed) Carbonatites, Genesis and Evolution. Unwin Hyman, London, pp 301-359

Dobretsov NL, Pokhilenko NP (2010) Mineral resources and development in the Russian Arctic. Russ Geol Geophys 51(1):98-111

Kravchenko SM, Pokrovsky BG (1995) The Tomtor alkaline ultrabasic massif and related REE$\mathrm{Nb}$ deposits, Northern Siberia. Econ Geol 90(3):676-689

Lazareva EV, Zhmodik SM, Dobretsov NL et al (2015) Main minerals of abnormally high-grade ores of the Tomtor deposit (Arctic Siberia). Rus Geol Geophys 56(6):844-873

Olary MO (1988) Carbon isotopes in photosynthesis. Bioscience 38(5):328-336

Pokrovsky BG, Belyakov AYu, Kravchenko SM et al (1990) Origin of carbonatites and orebearing rocks of the Tomtor massif, NW Yakutia, according to isotopic data. Geokhimiya (9):1320-1329. (in Russia)

Ribeiro CC, Brod JA, Junqueira-Brod TC, Gaspar JC, Petrinovic IA (2005) Mineralogical and field aspects of magma fragmentation deposits in a carbonate-phosphate magma chamber: evidence from the Catalão I complex, Brazil. J South Am Earth Sci 18(3-4):355-369

Open Access This chapter is licensed under the terms of the Creative Commons Attribution 4.0 International License (http://creativecommons.org/licenses/by/4.0/), which permits use, sharing, adaptation, distribution and reproduction in any medium or format, as long as you give appropriate credit to the original author(s) and the source, provide a link to the Creative Commons license and indicate if changes were made.

The images or other third party material in this chapter are included in the chapter's Creative Commons license, unless indicated otherwise in a credit line to the material. If material is not included in the chapter's Creative Commons license and your intended use is not permitted by statutory regulation or exceeds the permitted use, you will need to obtain permission directly from the copyright holder.

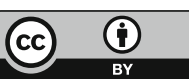

